\title{
PENGARUH PROSENTASE ETANOL TERHADAP TORSI DAN EMISI MOTOR INDIRECT INJECTION DENGAN MEMODIFIKASI ENGINE CONTROLE MODULE
}

\author{
Hadi Rahmad, Mega Nur Sasongko, Widya Widjayanti \\ Jurusan Teknik Mesin Fakultas Teknik Universitas Brawijaya \\ JIn. MT. Haryono 167 Malang 65145 \\ Telp (0341) 554291 \\ Email: hadirahmadsmknudanawu@yahoo.co.id
}

\begin{abstract}
This research present the torque and exhaust emission level from four stroke indirect injection fuel system engine. An engine fueled by ethanol gasoline blend. The original Engine Controle Module injected lean mixture into Combustion Chamber. Lean Mixture decreased Torque drastically. Therefore, the Engine Controle Module was modified to produce stoichiometric mixture. Injector was controlled by digital pulse of Fuel Controller. Ethanol was added into gasoline $0 \%-100 \%$ at $1500 \mathrm{rpm}-5000 \mathrm{rpm}$. The result demonstrate that increasing ethanol concentration into gasoline fuel system, decreasing Torque, and $\mathrm{CO}, \mathrm{HC}, \mathrm{CO}_{2}$ emission. $\mathrm{By}$ increasing ethanol concentration also increase $\mathrm{CO}_{2}$ emission to $34.6 \%$.
\end{abstract}

Keyword: Ethanol, Engine Controle Module, Torque, $\mathrm{HC}, \mathrm{CO}, \mathrm{CO}_{2}$

\section{PENDAHULUAN}

Berat molekul etanol lebih rendah bila dibandingkan dengan bensin. Hal ini juga berarti kandungan karbon dan hidrogennya juga semakin rendah. Sehingga kalau dihitung nilai Lower Heating Value (LHV) juga lebih rendah jika dibandingkan dengan bensin. Sehingga panas yang dihasilkan dari proses pembakaran akan lebih rendah. Hal ini juga berarti bahwa energi yang dihasilkan untuk menekan batang torak (connecting rod) juga semakin kecil jika dibandingkan dengan bensin sehingga Torsinya juga akan turun karena efisiensi panas selalu sebanding dengan torsi mesin pada pembakaran setiap massa udaranya. Akibatnya Torsi yang dihasilkan akan berkurang.

Etanol memiliki kandungan Karbon dan hydrogen yang lebih rendah maka kandungan Oksigen $\left(\mathrm{O}_{2}\right)$ akan semakin tinggi. Sehingga menggunakan bahan bakar etanol membuat pembakaran menjadi sempurna karena kandungan oksigen lebih banyak dibandingkan dengan bensin. Jika kendaraan menggunakan etanol lebih banyak maka kandungan $\mathrm{CO}, \mathrm{HC}$ dan $\mathrm{CO}_{2}$ akan cenderung turun

Dengan menggunakan media standart dari pabrik maka penurunan torsi terjadi cukup tinggi dikarenakan nilai kalor yang rendah dari etanol yang membuat temperatur mulai langkah hisap dan temperatur akhir pembakaran. Selain itu yang membuat penurunan torsi yang lainnya yaitu campuran yang masuk ke ruang bakar cenderung miskin karena program Engine Controle Module tidak dapat dirubah. Dengan tidak dapat dirubahnya program Engine Controle Module maka injektor hanya akan menyemprotkan bahan bakar sesuai program dari ECM motor bensin. Penyemprotannya hanya akan mencampur massa udara dengan massa etanol dengan perbandingan 1:15. Dan hal ini membuat campuran bahan bakar yang cenderung miskin. Campuran yang miskin akan membuat penurunan torsi yang sangat tinggi.

Untuk mengurangi penurunan torsi yang terjadi pada motor standart dan untuk mengetahui seberapa kadar emisi yang dihasilkan maka peneliti membuat pengontrol bahan bakar. Pengontrol bahan bakar (fuel controller) akan memberikan signal kepada injektor berupa signal digital sesuai keinginan peneliti. Sehingga dengan fuel controller tersebut campuran yang masuk ke ruang bakar dapat dijaga pada kondisi ideal (stoikiometri).

Dengan kondisi yang stoikiometri akan didapatkan penurunan torsi yang tidak terlalu 
tinggi dalam upaya mempertinggi efisiensi bahan bakar. Dengan fuel controller campuran yang masuk ke dalam ruang bakar diatur dengan cara membuat pengatur yang dapat mengatur signal digital yang masuk ke dalam injector dengan cara mengatur dutycyclenya. Sehingga dengan pengaturan itu, peneliti bisa mendapatkan campuran yang ideal. Dengan pengaturan ini maka data yang akan dihasilkan diharapkan lebih akurat.

\section{METODOLOGI PENELITIAN}

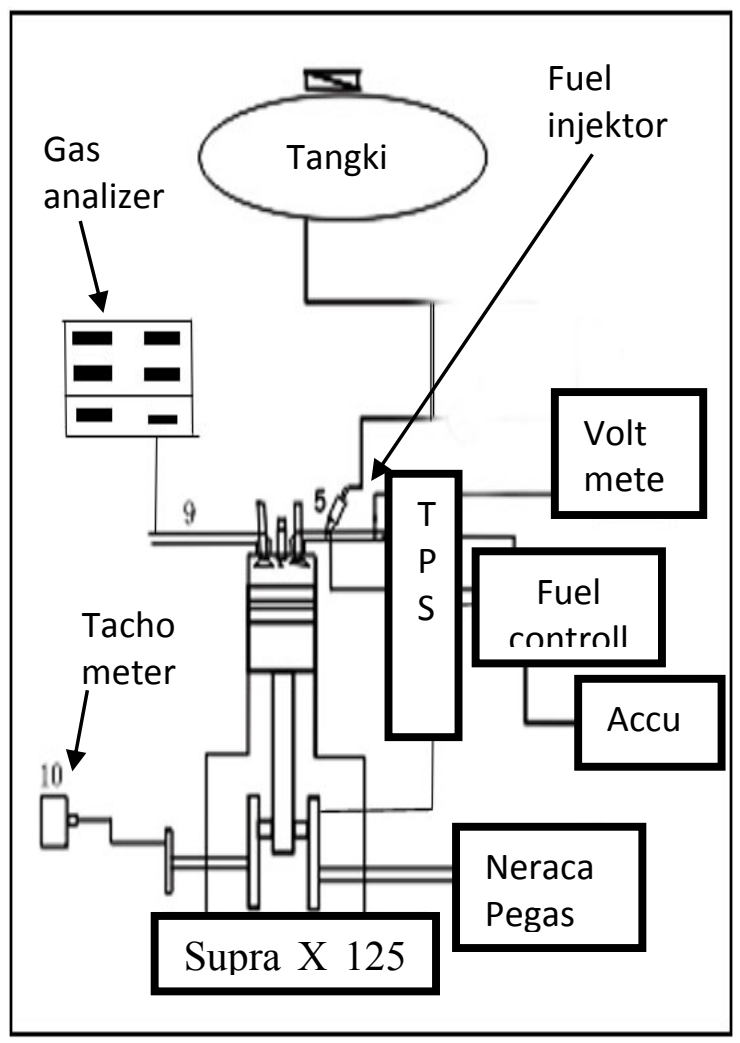

Gambar 1. Skema Instalasi Penelitian

Penelitian ini menggunakan motor HONDA PGMFI. Namun dengan kondisi standart mesin PGMFI tidak mampu menjaga kondisi campuran hingga mencapai 1. Dengan adanya kekurangan tersebut maka peneliti membuat Fuel Controller untuk mengatur Jumlah bahan bakar yang diinjeksikan dengan mengatur Dutycycle dan Frekwensi seperti terlihat pada Gambar 2 dengan menggunakan Mikro Kontroller Atmega 16

Dengan Fuel Controller mampu mengambil alih kerja injektornya dengan memberikan Signal digital pada transistor PNP sehingga Transistor mampu mengendalikan injector dengan menghubungkannya ke massa. Dengan dihubungkannya ke massa jika injector telah dialiri arus listrik maka injector akan membuka. Sebaliknya jika transistor tidak menghubungkan injektor ke massa maka injektor akan menutup. Lama membuka dan menutupnya injektor dapat dikendalikan sesuai kebutuhan peneliti.

Udara masuk melalui throttle body dan diatur oleh Throtle Position Sensor (TPS). Pengaturan pembukaan derajat katup gasnya tergantung peneliti. Karena TPS berupa Potensiometer maka jika gas dibuka maka Signal tegangan analognya disalurkan melalui kabel Vta memberikan signal ke fuel controller. Fuel controller mengolah signal itu sebagai inputan. Fuel Controller mengkonversi signal analog tersebut menjadi signal tegangan digital sehingga dapat digunakan untuk mengaktifkan Transistor NPN. Dengan adanya signal digital tersebut maka Injektor akan dihubungkan ke massa oleh transistor. Sehingga injektor menyemprot dan tidak menyemprot berdasarkan signal pengontrol bahan bakar (fuel controller).

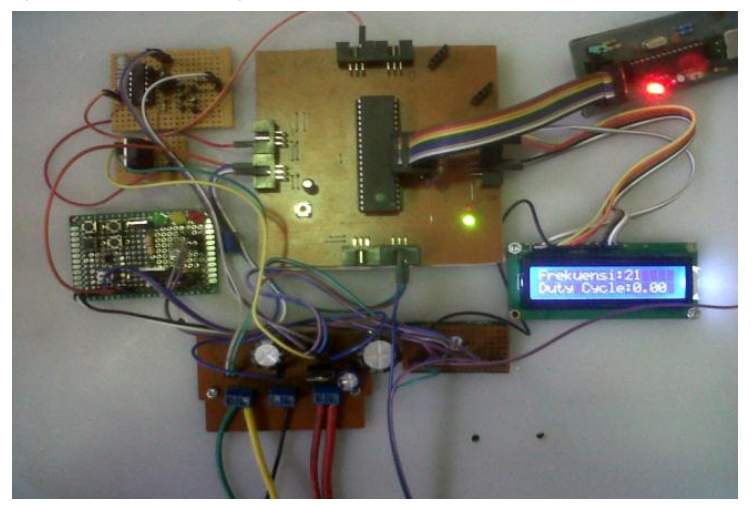

Gambar 2. Fuel controller (pengatur jumlah bahan bakar yang diinjeksikan)

Penyemprotan injektor dapat diatur dengan menekan tombol (push button) pada fuel controller. Jika menghendaki suplai bahan bakar lebih banyak maka peneliti tinggal menekan tombol Dutycycle. Penambahan angka Dutycycle (DC) maka durasi penyemprotan pada frekwensi tertentu akan semakin panjang. Karena dutycycle adalah perbandingan antara waktu injektor 
menyemprot ( $\begin{array}{ll}T & \text { On) dengan Waktu yang }\end{array}$ dibutuhkan dalam satu periode.

Dengan skema penelitian ini campuran bahan bakar dapat langsung dilihat pada gas analyzer. Ketika nilai lambda $(\lambda)$ mendekati 1 maka dapat disimpulkan bahwa campuran bahan bakar dan udara sudah ideal. Apabila nilai lambda melebihi 1 maka campuran terlalu miskin. Oleh karenanya supaya nilai lambda mendekati 1 maka peneliti tinggal menekan tombol untuk mempertinggi Dutycycle. Karena nilai lambda adalah perbandingan udara yang sebenarnya / udara teoritis. Jika nilai lambda terlalu tinggi maka sebenarnya jumlah udara yang masuk ke dalam ruang bakar (combustion chamber) terlalu banyak untuk itu campuran harus ditambah suplay bahan bakar. Begitu pula jika sebaliknya.

Dalam menentukan dutycycle yang paling tepat untuk mendapatkan campuran bahan bakar yang stoichiometri memerlukan pasangan-pasangan harga Tegangan yang dikeluarkan oleh Throtle Position Sensor (TPS) ke Fuel Controller, Frekwensi, Dutycycle, Putaran Motor. Sehingga didapatkan pasangan harga pada setiap beberapa derajat pembukaan katup gas nya. Pengambilan data emisi gas buang harus berdasarkan pasangan-pasangan harga tegangan, Frekwensi, dutycycle, Jumlah putaran maksimal. Sehingga didapatkan kadar CO, $\mathrm{HC}, \mathrm{CO}_{2}$ pada masing-masing perubahan bahan bakarnya. Setelah selesai mengambil data Kadar $\mathrm{CO}, \mathrm{HC}, \mathrm{CO}_{2}$ dari Gas Analizer maka pasangan harga diatas dapat digunakan untuk mengambil data Torsi. Selanjutnya mengambil data Torsi yang dihasilkan. Sesuai Pasangan harga yang sudah didapatkan pada tahapan sebelumnya maka didapatkan beban pengereman untuk dasar mendapatkan Torsi yang dihasilkan.

\section{HASIL DAN PEMBAHASAN}

Pada putaran 1500 rpm torsi paling tinggi didapatkan pada bahan bakar tanpa penambahan etanol. Setelah ditambah etanol $10 \%$ torsi menjadi turun $1,4 \%$. Dilanjutkan dengan penambahan etanol $20 \%$ Torsi tidak mengalami penurunan. Setelah prosentase etanol ditambah hingga $30 \%$ Torsi turun hingga $2,9 \%$. Torsi turun lagi hingga $5,8 \%$ pada penambahan etanol sebanyak $40 \%$ dan $50 \%$. Prosentase etanol $60 \%$ dan $70 \%$ mengakibatkan turunnya Torsi hingga 8,8\%. Penurunan terus terjadi pada penambahan etanol sebesar $80 \%$ dan $90 \%$ yaitu masingmasing $10,3 \%$ dan $11,8 \%$. Penurunan terbesar pada $100 \%$ etanol yaitu mencapai $14 \%$.

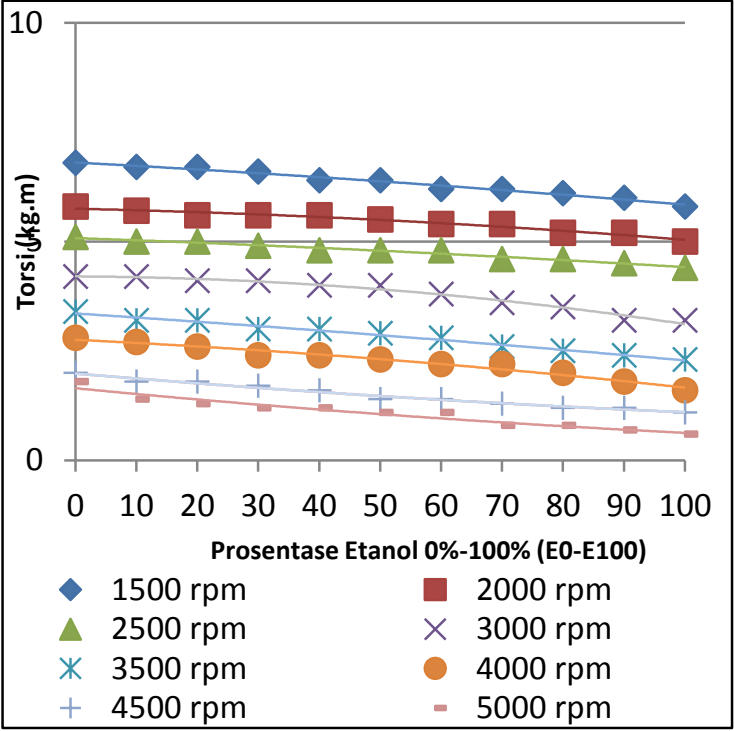

Gambar 3. Grafik Pengaruh Prosentase Etanol terhadap Torsi.

Dari hasil diatas secara umum pada semua putaran terjadi penurunan Torsi. Penurunan torsi tertinggi terjadi pada prosentase etanol $100 \%$ jika dibandingkan dari sekian banyak data yang dihasilkan pada putaran 1500 rpm sampai dengan 5000 rpm. Hal ini disebabkan karena etanol memiliki nilai kalor (heating value) yang lebih rendah sehingga etanol mengurangi temperatur silinder yang dapat mengakibatkan misfire dan akhirnya menurunkan Torsi seperti telah disampaikan oleh peneliti terdahulu [1].

\section{Pengaruh Prosentase Etanol pada Emisi CO}

Pada Gambar 4 menunjukkan pengaruh prosentase etanol terhadap kadar $\mathrm{CO}$ yang dihasilkan. Kadar CO dapat langsung dibaca pada Gas analyzer. Pada putaran rendah yaitu 1500 rpm kadar CO yang dihasilkan tanpa adanya penambahan etanol ( $0 \%$ etanol) adalah $0,06 \%$. Setelah ditambahkan kadar etanolnya menjadi $10 \%$ kadar CO turun hingga $8,3 \%$. Penambahan etanol dilanjutkan sampai prosentase $20 \%$ juga terus menurunkan kadar CO hingga $33,3 \%$. Penurunan terus terjadi pada penambahan etanol sampai $30 \%$ 
menghasilkan kadar CO sebesar $50 \%$. Penambahan kadar etanol sampai $40 \%$ mengalami sedikit kenaikan dibanding dengan prosentase etanol $30 \%$ yaitu $41,6 \%$. Penambahan etanol $50 \%$ menurunkan kadar CO menjadi $45 \%$. Namun penambahan etanol menjadi $60 \%$ penurunan kadar CO tidak sebanyak kadar $\mathrm{CO}$ yang dihasilkan prosentase etanol 50\%. Penambahan etanol sampai $70 \%$ menghasilkan $\mathrm{CO}$ sebesar $38 \%$. Penambahan etanol sampai $80 \%$ juga terus menurunkan kadar CO sampai $58 \%$. Penurunan terus terjadi pada penambahan etanol sampai $90 \%$ yaitu sebesar 63 . Penurunan terbesar terjadi pada penambahan etanol $100 \%$ yaitu sampai $66 \%$.

Dari hasil hubungan antara prosentase ethanol dengan kandungan $\mathrm{CO}$ pada berbagai putaran mesin didapatkan bahwa munculnya gas CO pada sisa hasil pembakaran merupakan kerugian dalam reaksi antara bahan bakar dan udara. Kerugian ini disebabkan karena adanya atom $\mathrm{C}$ yang tidak berikatan dengan $\mathrm{O}_{2}$ sehingga pembakaran berlangsung secara tidak sempurna dimana penyemprotan bahan bakar tidak menghasilkan partikel yang cukup kecil. Dari Gambar 4 dapat dilihat pada semua prosentase etanol, kandungan $\mathrm{CO}$ cenderung turun seiring bertambahnya prosentase ethanol dalam bahan bakarnya. Hal ini disebabkan karena adanya kandungan $35 \%$ oksigen dalam setiap molekul ethanol sehingga oleh peneliti terdahulu disebutkan sebagai Partially Oxidized Hydrocarbon yang akan memiliki peluang untuk membuat $C$ berikatan dengan Oksigen untuk membentuk $\mathrm{CO}_{2}$ [1]. Sehingga CO menjadi turun. Diperkuat juga dengan pernyataan peneliti terdahulu bahwa kadar $\mathrm{CO}$ pada saluran buang selalu ada meskipun campuran miskin [2]. Tetapi kadarnya dapat berkurang dengan penurunan temperatur pembakaran. Karena low Heating Value rendah maka panas hasil pembakaran akan turun. Sehingga juga menurunkan kadar $\mathrm{CO}$.

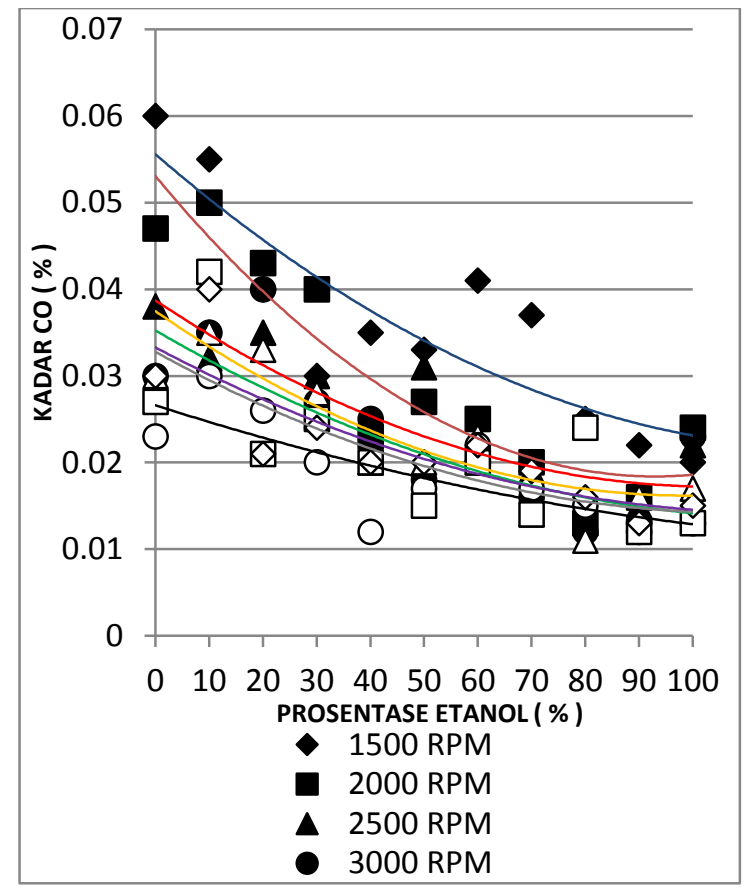

Gambar 4. Hubungan prosentase etanol dengan kandungan $\mathrm{CO}$

\section{Pengaruh Prosentase Etanol Terhadap Emisi HC}

Gambar 5 menunjukkan hubungan prosentase etanol terhadap kadar HC yang dihasilkan. Dari Gambar tersebut dapat dilihat pada putaran $1500 \mathrm{rpm}$ menghasilkan kadar HC sebesar 160 ppm. Setelah ditambahkan $10 \%$ etanol terjadi penurunan kadar HC sebanyak $4,3 \%$. Penurunan kadar $\mathrm{HC}$ terus bertambah setelah ditambahkan kadar etanol menjadi $20 \%$ yaitu sebesar $5 \%$. Penambahan kadar etanol terus ditambah menjadi $30 \%$ menurunkan produksi HC sebanyak $12,5 \%$. Penurunan HC sampai $28,1 \%$ jika bahan bakar menggunakan prosentase etanol $40 \%$. Penurunan terus terjadi pada penambahan prosentase etanol sampai $50 \%$ yaitu sebesar $44,3 \%$. Penurunan setelah diberi etanol sampai $60 \%$ lebih kecil dari $50 \%$ etanol yaitu hanya sebesar $41,8 \%$. Penurunan tertinggi terjadi pada penambahan etanol $90 \%$ yang dapat menurunkan kadar HC sampai $60 \%$. Pada prosentase etanol $100 \%$ sedikit mengalami penurunan yaitu hanya $51 \%$.

Hidrokarbon (HC) adalah ikatan unsur dari hidrogen dan karbon yang tidak terbakar pada saat proses pembakaran tidak sempurna di 
ruang bakar dimana hanya sebagian bahan nilai 160 ppm. Sehingga dapat diambil bakar bereaksi dengan oksigen $\left(\mathrm{O}_{2}\right)$. Pada kesimpulan bahwa semakin tinggi kadar etanol, Gambar 5 dapat dilihat pada setiap variasi semakin rendah kadar HC yang dihasilkan. Hal putaran kandungan $\mathrm{HC}$ cenderung turun seiring ini sesuai dengan pernyataan peneliti terdahulu bertambahnya prosentase etanol mulai dari $0 \%$ bahwa etanol sebagai Partially Oxidized sampai $100 \%$. Hal ini dikarenakan adanya Hydrocarbon [1].

penambahan oksigen sehingga pembakaran menjadi lebih sempurna sehingga mengurangi kadar HC seperti telah dijelaskan oleh peneliti terdahulu bahwa etanol sebagai partially oxidized hydrocarbon [3].

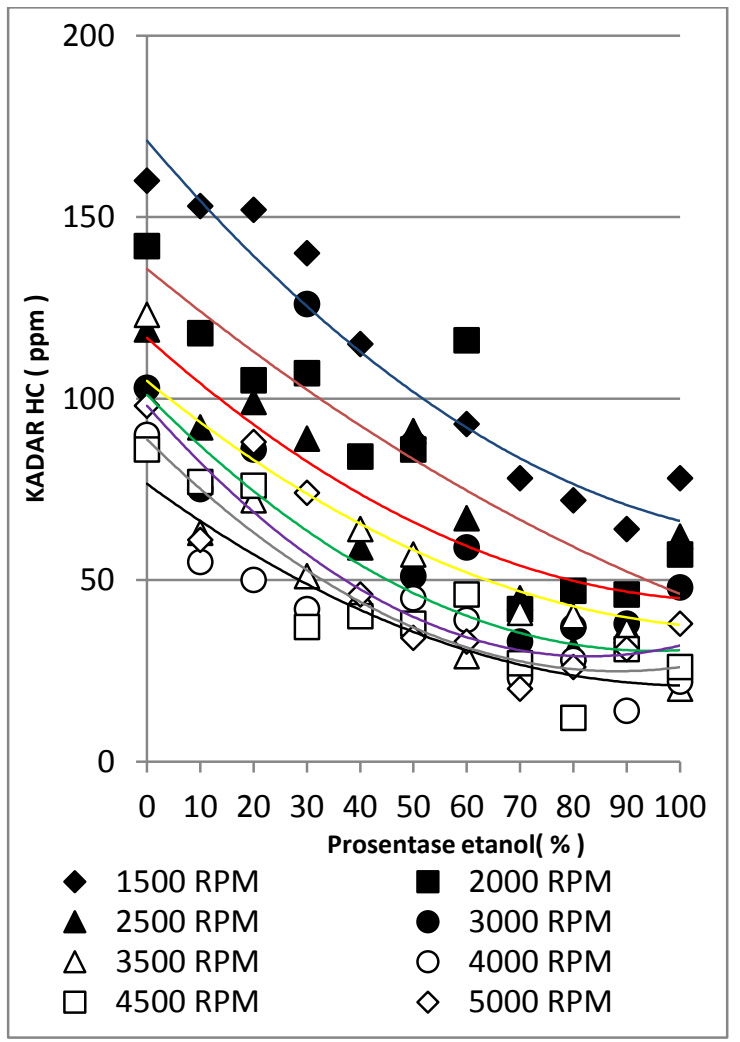

Gambar 5. Hubungan antara Prosentase etanol dengan kandungan $\mathrm{HC}$.

Pembakaran yang terjadi pada AFR stoikiometri akan menghasilkan emisi yang lebih rendah. Pengaturan frekuensi dan dutycycle dengan Fuel Controller untuk mendapatkan AFR stoikiometri juga sangat membantu dalam menghasilkan emisi yang lebih rendah karena pembakaran berlangsung secara lebih sempurna. Kadar terendah HC terdapat pada prosentase etanol $80 \%$ dengan putaran 4500 dengan nilai 12 ppm (part per million) dan kadar $\mathrm{HC}$ tertinggi terdapat pada kadar ethanol E0 dengan putaran 1500 dengan

\section{Pengaruh Prosentase Etanol pada Emisi $\mathrm{CO}_{2}$}

Pada Gambar 6 dapat dilihat hubungan prosentase etanol dengan kadar $\mathrm{CO}_{2}$ yang dihasilkan. Putaran 1500 rpm menghasilkan kadar $\mathrm{CO}_{2}$ sebesar $6,6 \%$ pada pembakaran tanpa ditambahkan etanol $(0 \%$ etanol). Peningkatan kadar $\mathrm{CO}_{2}$ terjadi setelah ditambahkan $10 \%$ etanol sebesar $18,2 \%$. Penambahan etanol selanjutnya pada $20 \%$ etanol juga menghasilkan peningkatan $\mathrm{CO}_{2}$ sebesar 22,7\%. Pada penambahan etanol selanjutnya menjadi $30 \%$ etanol menunjukkan penurunan grafik karena hanya menghasilkan peningkatan $\mathrm{CO}_{2}$ sebesar $16,6 \%$. Lebih kecil dari prosentase etanol sebelumnya. Peningkatan kadar $\mathrm{CO}_{2}$ kembali terjadi dan grafik menunjukkan kenaikan pada prosentase etanol $40 \%$ yaitu sebesar $33,3 \%$. Pada putaran ini peningkatan $\mathrm{CO}_{2}$ tertinggi terjadi pada prosentase etanol $100 \%$ yaitu sebesar $43,9 \%$.

Dari grafik hubungan antara Prosentase etanol mulai $0 \%$ (E0) sampai dengan $100 \%$ etanol (E100) dengan kenaikan kadar ethanol $10 \%$ dan kandungan $\mathrm{CO}_{2}$ pada berbagai putaran mesin. Terdapatnya $\mathrm{CO}_{2}$ pada hasil pembakaran merupakan tan da bahwa pembakaran yang terjadi tercukupi oksigen sehingga pembakaran dapat terjadi dengan sempurna. Pada Gambar 5.4 diatas dapat dilihat pada setiap penambahan kadar ethanol kandungan $\mathrm{CO}_{2} \quad$ cenderung naik. Bertambahnya kandungan $\mathrm{CO}_{2}$ pada emisi gas buang dikarenakan semakin banyaknya kandungan oksigen yang terkandung dalam campuran sehingga atom $\mathrm{C}$ cendrung berikatan dengan $\mathrm{O}_{2}$ untuk membentuk $\mathrm{CO}_{2}$. Selain itu pengaturan banyaknya bahan bakar yang masuk ke ruang bakar melalui pengaturan frekuensi dan dutycycle akan menjadikan campuran bahan bakar berada di daerah stoikiometri. Dengan demikian reaksi pembakaran akan berlangsung dengan lebih sempurna. Kandungan $\mathrm{CO}_{2}$ terendah terdapat pada kadar etano/ $10 \%(E 10)$ dengan putaran 1500 dengan nilai $1,66 \%$ dan $\mathrm{CO}_{2}$ tertinggi 
terdapat pada kadar etanol $100 \%$ (E100) yang dihasilkan juga semakin turun. Penurunan dengan putaran 4500 dengan nilai $11,5 \%$. Hal torsi terbesar terjadi pada putaran motor 5000 ini juga sesuai dengan pernyataan [1] bahwa rpm dengan penambahan etanol $100 \%$ yaitu ada hubungan antara $\mathrm{CO}$ dengan $\mathrm{CO}_{2}$. Apabila sebesar $66 \%$. Dari data emisi yang dihasilkan $\mathrm{CO}$ yang dihasilkan Turun maka $\mathrm{CO}_{2}$ yang setelah ditambahkan etanol dengan prosentase dihasilkan akan naik. Seiring dengan kenaikan 10\% sampai 100\% terjadi perubahan kadar CO. kecepatan putaran motor. Begitu juga Semakin banyak etanol yang ditambahkan, sebaliknya jika $\mathrm{CO}_{2}$ yang dihasilkan turun, $\mathrm{CO}$ yang dihasilkan akan naik. $\mathrm{CO}_{2}$ yang dihasilkan juga tergantung pada perbandingan udara dan bahan bakar. Namun pada penelitian kali ini nilai lambda dijaga bernilai 1. Hal ini juga berarti bahwa perbandingan udara dan bahan bakar telah dijaga dengan campuran yang ideal sehingga data yang dihasilkan dapat digunakan sebagai acuan pembuatan teknologi motor dengan bahan bakar etanol.

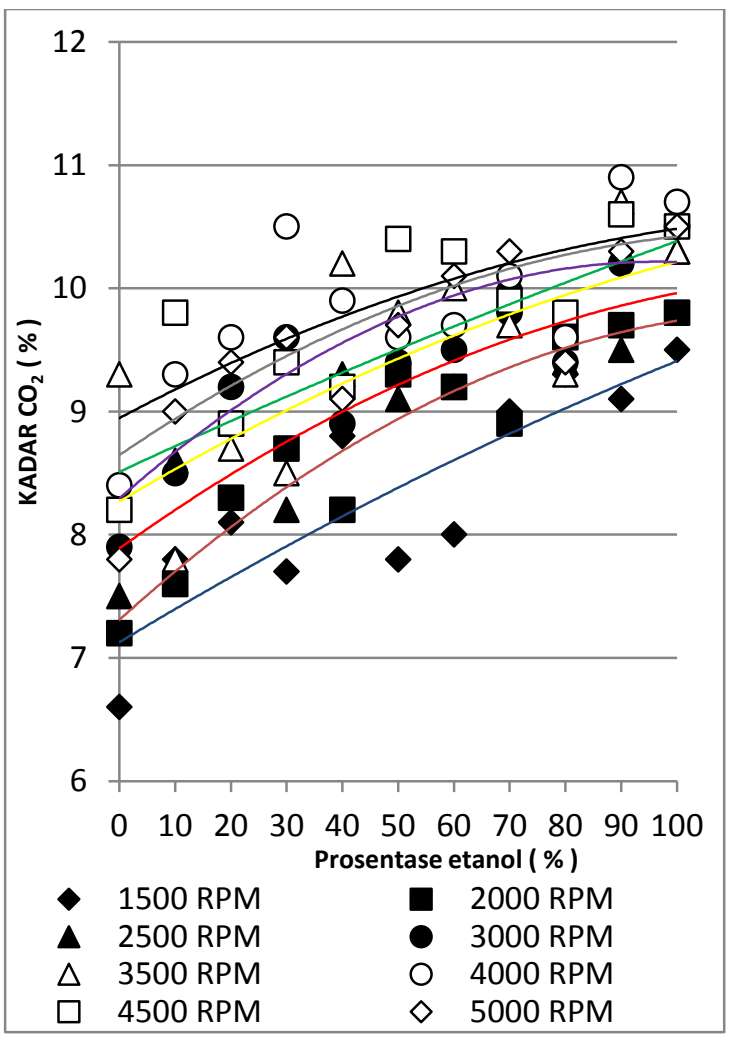

Gambar 6. Hubungan antara Prosentase etanol dengan kandungan $\mathrm{CO}_{2}$

\section{KESIMPULAN}

Dari data hasil penelitian yang telah didapatkan, dengan menambahkan etanol dengan prosentase $0 \%$ sampai $100 \%$. Semakin banyak etanol yang ditambahkan, maka torsi semakin tinggi pula penurunan kadar $\mathrm{CO}$ yang dihasilkan. Penurunan kadar $\mathrm{CO}$ yang dihasilkan terjadi pada putaran 5000 rpm. Penurunan tertinggi terjadi setelah ditambahkan etanol $90 \%$. Penurunan itu hingga mencapai $56,6 \%$. Selain itu data emisi yang didapatkan dari gas analyzer menunjukkan bahwa setelah ditambahkan prosentase etanol, kadar HC yang dihasilkan juga mengalami perubahan. Semakin tinggi prosentase etanol, semakin tinggi pula penurunan kadar $\mathrm{HC}$. Penurunan kadar $\mathrm{HC}$ tertinggi terjadi pada putaran $5000 \mathrm{rpm}$. Penurunan tertinggi terjadi setelah ditambahkan $70 \%$ etanol. Penurunan kadar $\mathrm{HC}$ tertinggi mencapai $79,6 \%$. Kadar $\mathrm{CO}_{2}$ yang dihasilkan juga mengalami perubahan. Semakin banyak prosentase etanol, maka semakin banyak juga kandungan $\mathrm{CO}_{2}$ yang dihasilkan. Peningkatan kadar $\mathrm{CO}_{2}$ tertinggi terjadi pada putaran $5000 \mathrm{rpm}$. Peningkatan $\mathrm{CO}_{2}$ tertinggi terjadi setelah penambahan etanol $100 \%$ (etanol murni). Peningkatan tertinggi mampu mencapai $34,6 \%$.

\section{DAFTAR PUSTAKA}

[1] Celik MB. 2008. Experimental determination of suitable ethanol-gasoline blend rate at high compression ratio for gasoline engine. Appl Thermal Eng. 28(5):396-404.

[2] Koc. M et al. 2009. The effects of ethanolunleaded gasoline blend on engine performance and exhaust emissions in a spark-ignition engine. Renewable Energy.(34) :2101-2106.

[3] Yang H. 2012. Effect of etanol-blended gasoline on emission of regulated air pollutants and carbonyl from motor cycle. Applied Energy (89):281-286. 